\title{
Assessment of the genotoxic impact of pesticides on farming communities in the countryside of Santa Catarina State, Brazil
}

\author{
Jaqueli Salvagni $^{1}$, Raquel Zeni Ternus ${ }^{1}$ and Alexandre Meneghello Fuentefria ${ }^{2}$ \\ ${ }^{1}$ Área de Ciências da Saúde, Universidade Comunitária da Região de Chapecó, Chapecó, SC, Brazil. \\ ${ }^{2}$ Departamento de Análises, Universidade Federal do Rio Grande do Sul, Porto Alegre, RS, Brazil.
}

\begin{abstract}
The aim of this study was to assess the use of pesticides on farms located in the Lambedor River watershed in Guatambu, State of Santa Catarina, as well as to determine, by micronucleus testing, the risk of genotoxic impact. Samples from locally collected Cyprinus carpio, Hypostomus punctatus, Rhamdia quelen and Oreochromis niloticus gave evidence of a mean increase in micronuclei frequency from 6.21 to 13.78 in 1,000 erythrocytes, a clear indication of the genotoxic potenciality of pesticide residues in regional dams, and their significant contribution to local environmental contamination.
\end{abstract}

Key words: pesticides, environment, micronucleus test.

Received: December 4, 2009; Accepted: September 6, 2010.

\section{Introduction}

Agrochemicals are widely used for decades, in an attempt to protect crops against insect pests. Nevertheless, in the light of the increasing resistance, every year a vast array of new compounds is introduced into the market, with consequential negative side effects and increased costs in food production. More specifically, pesticides are poisons intentionally dispersed in the environment to control pests, and which subsequently persist in the soil, water and food, with toxicity related outcomes to both humans and animals (Schulz, 2004; Carvalho, 2006; Moraes et al., 2009). Notwithstanding, the use of agrochemicals remains a common practice, especially in tropical regions (Carvalho, 2006).

Brazil is the the third main consumer of pesticides worldwide (Agriculture and Agri-Food, Canada, 2005). Numbers from the Brazilian pesticide industry show that pesticide sales in Brazil have risen from US\$ 0.98 billion in 1992 to US\$ 4.5 billion in 2004, this representing an increase of $360 \%$ over the period (Brazil, 2008). Furthermore, discrepancies between Brazilian regulation of the pesticide market, and those enforced in developed countries, have paved the way to the importation of vast amounts of pesticides that are highly toxic, severely restricted, or even banned in other nations (Carvalho, 2006; Smith, 2001).

According to Peres and Moreira (2007), the widespread and growing use of pesticides for raising crops and

Send correspondence to Alexandre Meneghello Fuentefria. Departamento de Análises, Faculdade de Farmácia, Universidade Federal do Rio Grande do Sul, Av. Ipiranga 2752, sala 304C, 90.610000 Porto Alegre, RS, Brazil. E-mail: alexmf77@gmail.com. cattle in Brazil has given rise to a number of environmental changes and problems, both by the contamination of human communities, as part of the environment, and by accumulation in biotic and abiotic segments of ecosystems. With year-round harvests, the low level of mechanization in the various phases of production, and the consequential exposure to multiple environmental contaminants (pesticides), the vulnerability of Brazilian workers and the environment itself to these genotoxic agents becomes evident.

Environmental quality control requires the monitoring of various indicators, including the assessment of pesticide residues. Research on bioindicators is instrumental in detecting the toxic effects caused by these. Processes in the bioconcentration and transformation of pesticides have been studied mainly in fishes. This is due to these animals living in direct contact with aquatic sediments adjacent to areas where pesticides are commonly used. In these water bodies, many poorly water-soluble compounds eventually settle, with the consequential increase in the degree of local contamination, when compared to the water column as a whole (Grisolia, 2005; Umbuziero et al., 2006).

In Brazil, reports on pesticide toxicity in fish are still rare. Nevertheless, in recent studies, potentially genotoxic substances have been recognized and quantified, when using fish as experimental organisms (Andrade et al., 2004). Nowadays, several tests have been well developed and standardized for assessing the genotoxic profile of a wide spectrum of substances. In comparison to other methods, the advantage of the simplicity of the micronucleus test facilitates counting the micronuclei in erythrocytes. Therefore, the test has been widely used to evaluate the 
mutagenic potential of new drugs and chemicals, being also indicated in routine screening and environmental monitoring (Al-Sabti et al., 1994; Bücker et al., 2006).

Micronuclei are formed during the telophase of mitosis or meiosis, when the nuclear envelope is reconstituted around the chromosomes of daughter cells (Udroiu, 2006). Micronuclei are the result of chromosome acentric fragments (clastogenic effect) or whole chromosomes that, through incomplete migration, have been excluded from the main core (aneugenic effect). Thus, micronuclei represent a loss in chromatin as a result of damage to either chromosome structure (fragmentation) or the mitotic apparatus. There may also be the formation of bilobed nuclei, thereby indicating an early change in cellular metabolism (Fenech, 2000; Grisolia and Cordeiro, 2000; Bombail et al., 2001; Grisolia and Starling, 2001).

Within this context, the aim was to survey the use of pesticides in Guatambu, Santa Catarina State, Brazil, and, through micronucleus testing, determine the risk and toxicological impact of pesticides contaminating regional dams.

\section{Material and Methods}

\section{Sampling}

The study was undertaken in a farming community which included members of the Lambedor River Watershed Association of Guatambu, in the west Santa Catarina State, southern Brazil, during April, 2009. Fish were collected in all the dams existing in agricultural rural properties (10 sampling areas), as shown in Figure 1.

Three fishes of similar size and weight (between $700 \mathrm{~g}$ and $900 \mathrm{~g}$ ) were collected with cast nets in each dam. Blood samples of approximately $40 \mu \mathrm{L}$ were taken from each by cardiac puncturing with sterile heparinized syringes and needles. Samples were transferred to labeled Eppendorf tubes containing EDTA, and then taken to the Toxicology Laboratory of the Community University of the Region of Chapecó for micronucleus testing.

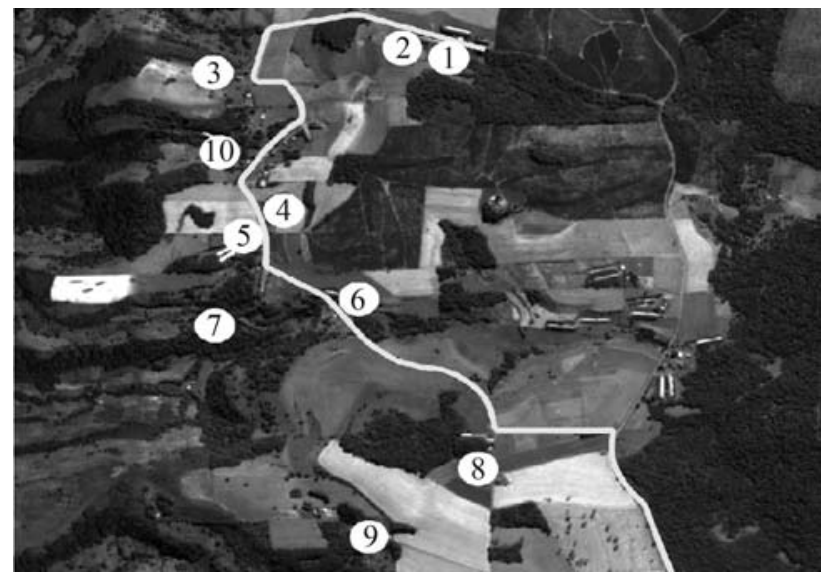

Figure 1 - Geographical location of sampling areas in the Lambedor River watershed, Guatambu, SC.

\section{The piscine micronucleus test}

Two blood smears per individual were prepared on clean microscope slides, to then be air-dried at room temperature. Subsequently, they were first fixed with absolute methanol for $10 \mathrm{~min}$ and then air-dried for at least $24 \mathrm{~h}$. After fixation, the slides were treated with $1 \mathrm{~N} \mathrm{HCl}$ for $11 \mathrm{~min}$ in a water-bath at $60{ }^{\circ} \mathrm{C}$. After washing with distilled water, they were then stained with a Schiff solution in the dark. In sequence, the slides were removed and left to dry at room temperature, for subsequent microscopic examination.

According to criteria already described by Ayllon and Garcia-Varquez (2000), only rounded non-refractive structures that had separated from the main nucleus were taken into account for micronuclei scoring. 3000 erythrocytes from each fish were counted (1000 erythrocytes on each slide) at $1000 \mathrm{x}$ magnification under an oil-immersion objective, end examined for micronucleated cells.

\section{Results}

The responses from the questionnaires showed regular use of pesticides in 100\% of sampling areas. As regards equipment washing, it was evident that $70 \%$, of the water is normally returned to the farm itself, the remainder being discarded onto the soil. The responses also revealed that farmers were uncertain as to the correct destination of empty containers.

The most widely used pesticides were Roundup ${ }^{\circledR}$ (Glyphosate), Karate ${ }^{\circledR}$ (Lambda Cyhalothrin), Herbimix ${ }^{\circledR}$ (Atrasine and Simazine) and Priori Xtra ${ }^{\circledR}$ (Azoxystrobin).

Cyprinus carpio, Hypostomus punctatus, Rhamdia quelen and Oreochromis niloticus figured among the animals collected in this study. Micronucleate erythrocytes (Figure 2) were found Mat different frequencies among the captured fish species, as shown in Figure 3, the highest mean values being observed in Cyprinus carpio (15.33 in Weir 4, 15.00 and 14.00 in Weir 8. Figure 4 shows the means of micronuclei per dam, being especially perceptible

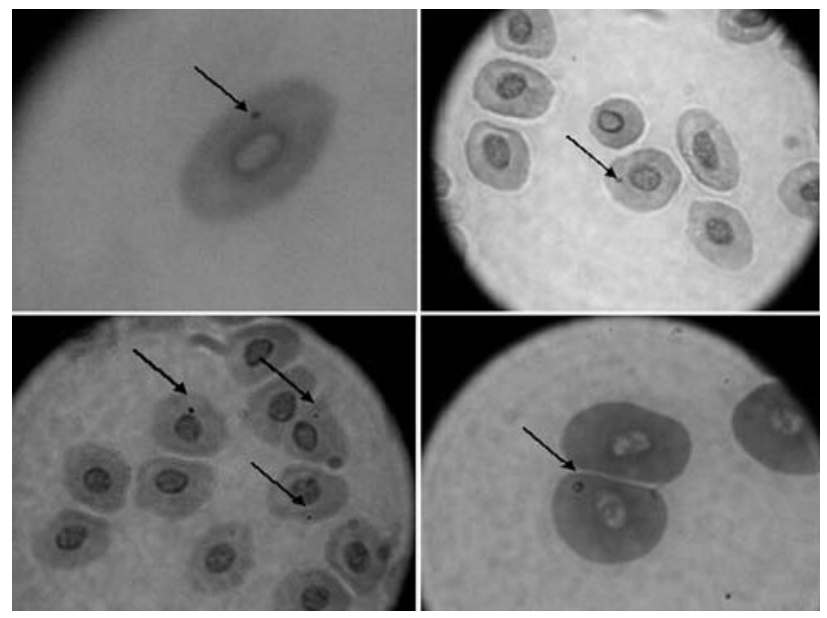

Figure 2 - Erythrocyte cells with the presence of micronuclei in fish collected from dams along the Lambedor River. 


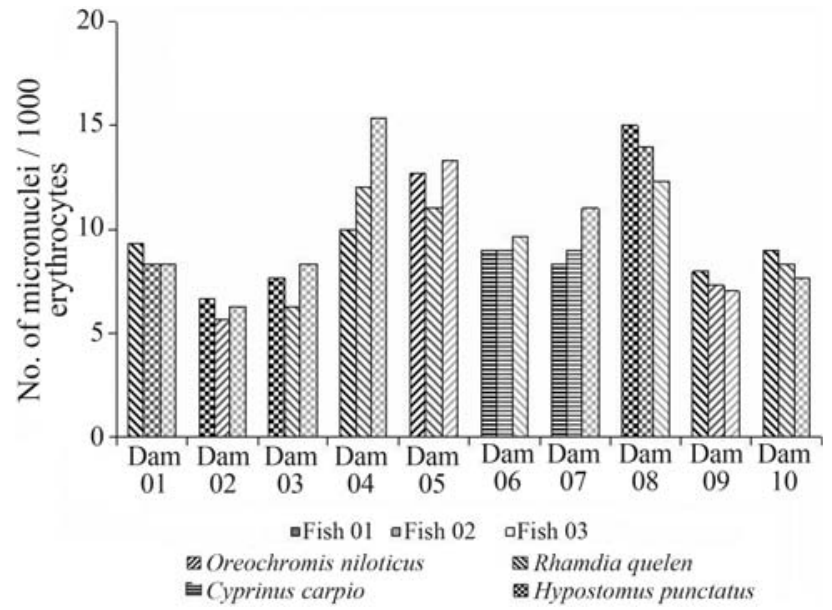

Figure 3 - Mean micronuclei frequency in fish collected from dams along the Lambedor River.

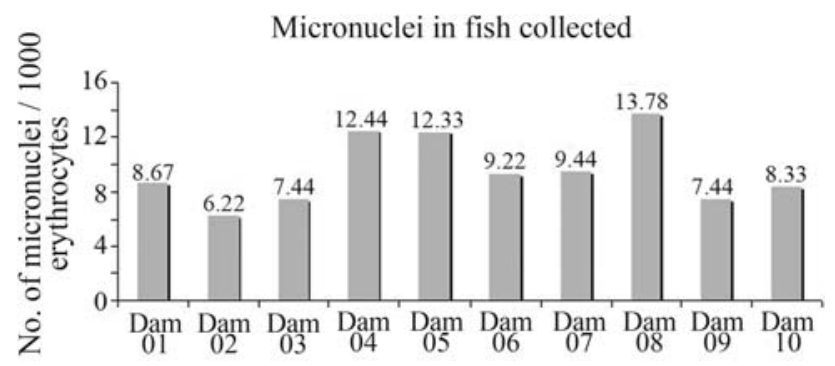

Figure 4 - Mean micronuclei frequency per dam along the Lambedor River.

in the larger sized sampling areas of Dams 4 (12.44) and Dam 8 (13.78). However, they were close to the overall average in Dam 5 (12.33), where the species collected were Rhamdia quelen and Oreochromis niloticus.

\section{Discussion}

The significant contribution to the environmental impact in the region, through the paramount, current use and handling of pesticides in small and middle-sized farms in the community, was amply proven. Induction of micronuclei was previously reported for fish collected in dams or rivers (Udroiu, 2006) and in situ quantification of micronuclei in piscine erythrocytes has been demonstrated to be an adequate biomarker in the evaluation of aquatic ecosystems quality (Ayllón and Garcia-Vazquez, 2000; Çavas and Ergene-Gözükara, 2003; Ergene et al., 2007).

The water used both in the preparation of the pesticide solutions and in the washing of utensils, is a relevant factor and possible source of poisoning. As reported by respondents, in the past the whole washing procedure was carried out near water sources or streams. It is known that, depending on the characteristics of the soil where disposal occurs, the contamination of both surface and ground water is a possibility, thereby constituting a contributing factor to environmental contamination (Peres and Moreira, 2007).
Of late, the effects of pesticides on aquatic organisms, especially when using non-lethal doses, have been amply demonstrated (Crestani et al., 2006; Veiga et al., 2006; Glusczak et al., 2007; Marques et al. 2007; Moraes et al., 2007; Fonseca et al., 2008; Miron et al., 2008). The processes of transport and impact on non-target organisms are governed by the rates of degradation and bioavailability of pesticides in soil or water, bioavailability itself depending on local physico-chemical and climatic conditions. Several factors influence the effects of pesticides on fishes, among others, the fish-species studied, the class, dose and concentration of the pesticide, and exposure time (Glusczak et al. 2006; Crestani et al., 2007; Moraes et al., 2007; Fonseca et al.; 2008, Cattaneo et al., 2008).

Lemos et al. (2005), on examining differences in response between species by in situ analysis, noted the appropriateness of the species Tilapia rendalli as a bioindicator of genotoxicity in a lake environment. According to Grisolia (2002), on exposure to different concentrations of glyphosate in the commercial formulation Roundup ${ }^{\circledR}$, there was an increase in the frequency of micronuclei in erythrocytes.

According to Grisolia (2005) and Udroiu (2006), the prevailing, extensive farming procedures, on inducing considerable impacts on the environment, are directly related to a reduction in biodiversity. The subsequent increase in mutation rate would lead to an increase in genetic load and a reduction in adaptive potential, with the consequential elimination of susceptible genotypes.

Apparently the action of any chemical genotoxic agent may give rise to an increase in micronucleus frequency. Consequently, based on the fact that spontaneous formation of micronuclei is normally low and nearly uniform among species (Siu et al., 2004), in environmental monitoring, micronucleus assaying has emerged as a simple, inexpensive and rapid method for detecting genotoxic effects.

Spontaneous formation of micronuclei in fish is normally very rare. In our study, however, significant frequencies were observed in the captured specimens from each dam, with micronucleus testing revealing the rate of micronucleated erythrocytes to be high, with a minimum of 6.21 and a maximum of 13.78 per 1,000 erythrocytes evaluated. When compared with the results obtained by RodriguezCea et al. (2003), with an average 3 micronuclei per 1000 erythrocytes examined, the above indices can be considered high. The data also further corroborated other studies in Brazil which showed a high incidence of micronuclei and nuclear abnormalities in organisms exposed to various chemicals (Matsumoto et al., 2006; Ventura et al., 2008).

In conclusion, it was proven through in vivo piscine micronucleus testing, that water from the Lambedor water-shed can be considered genotoxic, with emphasis on the degree of genotoxicity from pollution in the area. This implies the possibility of pesticide effluents discharged into 
the river constituting a disease-hazard to local populations. It is recommended that the river water be analyzed chemically, with a mind to identifying additional classes of toxicants that may also be contributing to genotoxicity in this specific water-shed.

\section{References}

Al-Sabti K, Franko M, Andrijanie B, Knez S and Stegnar P (1994) Chromium induced micronuclei in fish. J Appl Toxicol 14:333-336.

Andrade VM, Freitas TRO and Silva J (2004) Comet assay using mullet (Mugil sp.) and sea catfish (Netuma sp.) erythrocytes for the detection of genotoxic pollutants in aquatics environment. Mutat Res 560:57-67.

Ayllon F and Garcia-Vazquez E (2000) Induction of micronuclei and other nuclear abnormalities in European minnow Phoxinus phoxinus and mollie Poecilia latipinna: An assessment of the fish micronucleus test. Mutat Res 467:177-186.

Bombail V, Gordon AD and Batty J (2001) Application of the comet and micronucleus assays to butterfish (Pholis gunnellus) erythrocytes from the Firth of Forth, Scotland. Chemosphere 44:383-392.

Bücker A, Carvalho W and Alves-Gomes JA (2006) Avaliation of mutagenicity and gentotoxicity in Eigenmannia virescens (Teleostei, Gymnotiformes) exposed to benzene. Acta Amaz 36:357-364.

Carvalho FP (2006) Agriculture, pesticides, food security and food safety. Environ Sci Pol 9:685-692.

Cattaneo R, Loro VL, Spavenello R, Silveira FA, Luz L, Miron DS, Fonseca MB, Moraes BS and Clasen B (2008) Metabolic and histological parameters of silver catfish (Rhamdia quelen) exposed to commercial formulation of 2,4-dichlorophenoxiacetic acid (2,4-D) herbicide. Pestic Biochem Physiol 92:133-137.

Crestani M, Menezes C, Glusczak L, Miron DS, Lazzari R, Duarte MF, Morsch VM, Pippi AL and Vieira VP (2006) Effects of clomazone herbicide on hematological and some parameters of protein and carbohydrate metabolism of silver catfish Rhamdia quelen. Ecotoxicol Environ Saf 65:48-55.

Crestani M, Menezes CC, Glusczak L, Miron DS, Spavenello R, Silveira FA, Gonçalves FF, Zanella R and Loro VL (2007) Effect of clomazone herbicide on biochemical and histological aspects of silver catfish (Rhamdia quelen) and recovery pattern. Chemosphere 67:2305-2311.

Çavas T and Ergene-Gözükara S (2003) Micronuclei, nuclear lesions and interphase silver-staind nucleolar organizer regions (AgNORs) as cyto-genotoxicity indicators in Oreochromis niloticus exposed to textile mill effluent. Mutat Res 534:93-99.

Ergene S, Cavas T, Celik A, Köleli N and Aymak C (2007) Evaluation of river water genotoxicity using the piscine micronucleus test. Environ Mol Mutagen 48:421-429.

Fenech M (2000) The in vitro micronucleus technique. Mutat Res 455:81-95.

Fonseca MB, Glusczak L, Moraes BS, Menezes CC, Pretto A, Tierno MA, Zanella R, Gonçalves FF and Loro VL (2008) 2,4-D herbicide effects on acetylcholinesterase activity and metabolic parameters of piava freshwater fish (Leporinus obtusidens). Ecotoxicol Environ Saf 69:416-420.
Glusczak L, Miron DS, Crestani M, Fonseca MB, Pedron FA, Duarte MF and Vieira VLP (2006) Effect of glyphosate herbicide on acetylcholinesterase activity and metabolic and hematological parameters in piava (Leporinus obtusidens). Ecotoxicol Environ Saf 65:237-241.

Glusczak L, Miron DS, Moraes BS, Simões RR, Schetinger MRC, Morsch VM and Loro VL (2007) Acute effects of glyphosate herbicide on metabolic and enzymatic parameters of silver catfish (Rhamdia quelen). Comp Biochem Physiol C Toxicol Pharmacol 146:519-524.

Grisolia CK (2002) A comparison between mouse and fish micronucleus test using cyclophosphamide, mitomycin $\mathrm{C}$ and various pesticides. Mutat Res 518:145-150.

Grisolia CK (2005) Agrotóxicos: Mutações, Câncer e Reprodução. Editora da UNB, Brasilia, 392 pp.

Grisolia CK and Cordeiro CMT (2000) Variability in micronucleus induction with different mutagens applied to several species of fish. Genet Mol Biol 23:235-239.

Grisolia CK and Starling FLRM (2001) Micronuclei monitoring of fishes from Lake Paranoá, under influence of sewage treatment plant dischargers. Mutat Res 491:39-44.

Lemos NG, Dias AL, Silva-Souza AT and Mantovani MS (2005) Evaluation of environmental waters using the comet assay in Tilapia rendalli. Environ Toxicol Pharmacol 19:197-201.

Marques MN, Badiru AI, Beltrame O and Pires MAF (2007) Pesticide leaching and run-off hazard in the Ribeira de Iguape River Basin in São Paulo State, Brazil. J Braz Soc Ecotoxicol 2:179-185.

Matsumoto ST, Mantovani MS, Malagutti MIA, Dias AL, Fonseca IC and Marin-Morales MA (2006) Genotoxicity and mutagenicity of water contamined with tannery, as evaluated by the micronucleus test and comet assay using the fish Oreochromis niloticus and chromosome aberration in onion root-tips. Genet Mol Biol 29:148-158.

Miron D, Pretto A, Crestani M, Glusczak L, Schetinger M, Loro VL and Morsch V (2008) Biochemical effects of clomazone herbicide on piava (Leporinus obtusidens). Chemosphere $74: 1-5$.

Moraes BS, Loro VL, Glusczak L, Pretto A, Menezes C, Marchezan E and Machado SO (2007) Effects of four rice herbicides on some metabolic and toxicology parameters of teleost fish (Leporinus obtusidens). Chemosphere 68:1597-1601.

Moraes BS, Loro VL, Pretto A, Fonseca MB, Menezes C, Marchezan E, Reimche GB and Avila LA (2009) Toxicological and metabolical parameters of the teleost fish (Leporinus obtusidens) in response to commercial herbicides containing clomazone and propanil. Pestic Biochem Physiol 95:57-62.

Peres F and Moreira JC (2007) Health, environment, and pesticide use in a farming area in Rio de Janeiro State, Brazil. Cad Saúde Publica 23:612-621.

Rodriguez-Cea A, Ayllon F and Garcia-Vazquez E (2003) Micronucleus test in freshwater species: An evaluation of its sensitivity for application in eld surveys. Ecotoxicol Environ Saf 56:442-448.

Schulz R (2004) Field studies on exposure, effects, and risk mitigation of aquatic nonpoint-source insecticide pollution: A review. J Environ Qual 33:419-448.

Smith C (2001) Pesticide exports from US ports, 1997-2000. Int J Occup Med Environ Health 7:226-274. 
Siu WHL, Mak E, Jia C, De Luca-Abboty SB, Richardson BJ and Lam PKS (2004) Micronucleus induction in gill cells of green-lipped mussels (Perna viridis) exposed to mixtures of polycyclic aromatic hydrocarbons and chlorinated pesticides. Environ Toxicol Chem 232:1317-1325.

Udroiu I (2006) The micronucleus test in piscine erythrocytes. Aquat Toxicol 79:201-204.

Umbuziero GA, Kummrow F, Roubicek DA and Tominaga MY (2006) Evaluation of the water genotoxicity from Santos Estuary (Brazil) in relation to the sediment contamination end effluent discharges. Environ Internat 32:359-364.

Veiga MM, Silva DM, Veiga LBE and Faria MVC (2006) Pesticide pollution in water systems in a small rural community in Southeast Brazil. Cad Saúde Publica 22:2391-2399.

Ventura BC, Angelis DF and Marin-Morales MA (2008) Mutagenic and genotoxic effects of the Atrazine herbicide in
Oreochromis niloticus (Perciformes, Cichlidae) detected by the micronuclei test and the comet assay. Pestic Biochem Physiol 90:42-51.

\section{Internet Resources}

Brazil - Ministry of Agriculture, 2008 (2008) Statistics. Available at http://www.agricultura.gov.br/ (accessed May, 2010).

Agriculture and Agri-Food Canada, 2005 (2005) Agriculture and Agri-Food Canada, 2005. Agri-Food past, present \& future: Brazil, Canada, Ontario. Available at www.ats.agr.gc.ca/latin/4034 (accessed May, 2010).

$$
\text { Associate Editor: Catarina S. Takahashi }
$$

License information: This is an open-access article distributed under the terms of the Creative Commons Attribution License, which permits unrestricted use, distribution, and reproduction in any medium, provided the original work is properly cited. 